Relations industrielles

Industrial Relations

\title{
Bryon PALMER : Working-Class Experience : The Rise and Reconstitution of Canadian Labour, 1800-1980. Toronto, Butterworths, 1983, 320 pp.
}

\section{Jerry P. White}

Volume 40, numéro 2, 1985

URI : https://id.erudit.org/iderudit/050147ar

DOI : https://doi.org/10.7202/050147ar

Aller au sommaire du numéro

Éditeur(s)

Département des relations industrielles de l'Université Laval

ISSN

0034-379X (imprimé)

1703-8138 (numérique)

Découvrir la revue

Citer ce compte rendu

White, J. P. (1985). Compte rendu de [Bryon PALMER : Working-Class Experience : The Rise and Reconstitution of Canadian Labour, 1800-1980. Toronto, Butterworths, 1983, 320 pp.] Relations industrielles / Industrial Relations, 40(2), 408-409. https://doi.org/10.7202/050147ar

Tous droits réservés (C) Département des relations industrielles de l'Université Laval, 1985
Ce document est protégé par la loi sur le droit d'auteur. L'utilisation des services d'Érudit (y compris la reproduction) est assujettie à sa politique d'utilisation que vous pouvez consulter en ligne.

https://apropos.erudit.org/fr/usagers/politique-dutilisation/ 
pensée marxiste (Michel Pelletier) et la tradition utopique (Paul Beaulieu). Ces textes sont précédés d'un article d'introduction par Fernand Dumont qui insiste sur l'importance de chercher à comprendre le travail dans son rapport avec le temps libre. Ce rapport a pris des formes différentes au cours de l'histoire; ce qui le caractérise dans les sociétés occidentales contemporaines, c'est la distinction nette qu'elles font entre travail et «loisir», qui, pour beaucoup, «est devenu disponibilité pour la liberté». Si on comprend l'usage qui est fait de cette liberté, on comprendra mieux le sens que les hommes donnent à leur travail: pour Dumont, «une sociologie et une éthique du travail sont indissociables d'une sociologie et d'une éthique du loisir», un avis que les sociologues du travail ont intérêt à méditer. Dumont rappelle que plus les travailleurs utilisent leur temps libre de façon créatrice, plus la rationalisation à outrance du travail leur devient inacceptable et soulève des résistances. On peut donc se demander combien de temps encore une organisation taylorienne $\mathrm{du}$ travail pourra continuer à coexister avec une vie hors-travail organisée sur un autre mode qui en est la contradiction même.

L'autre ensemble de textes est composé de courts articles sur divers thèmes comme le travail des jeunes, des femmes, des travailleurs âgés, des cadres, le travail précaire, les fermetures d'usines, etc. Certains de ces articles viennent de la plume de chercheurs universitaires, d'autres de militants de mouvements sociaux ou de syndicats. Cette partie vogue entre l'analyse et la dénonciation et surtout n'apporte pas d'idées vraiment nouvelles; après les articles soignés de la première partie, celle-ci détonne un peu.

Ce recueil montre bien comment, historiquement, le travail a pris différents sens: travail-punition, travail-sacrifice, travail exploité ou travail libérateur. Il montre surtout la centralité du travail dans la vie des hommes et des femmes: les articles de la deuxième partie qui dénoncent les conséquences négatives de l'exclusion du marché du travail, que ce soit par le chômage, l'incapacité d'accéder à un emploi stable ou la retraite, illustrent à leur façon le rôle-clé du travail-marchand dans les sociétés contemporaines. Sans emploi rémunéré, on est condamné à vivre en marge sans statut reconnu et surtout sans les ressources qui permettent de satisfaire les be soins que nos sociétés de consommation ne cessent de multiplier.

Pourrons-nous encore longtemps accorder autant de valeur au travail alors que les mutations techniques que permettent les développements spectaculaires de l'informatique et des biotechnologies substituent de plus en plus systématiquement des automatismes au travail humain? Peut-être pour la première fois dans l'histoire allons-nous connaître simultanément la croissance économique et celle du chômage; à tout le moins, les techniques nouvelles le permettent. Nous serons confrontés à un formidable problème de redistribution qui nous obligera à remettre en question l'équation travail-source de revenu; il est possible, certains disent probable, que bientôt une minorité de personnes seulement travaillera au sens actuel d'occuper un emploi. Les autres devront tirer leur subsistance d'une autre source que l'emploi rémunéré, mais surtout, ils devront donner un autre sens à leur vie, combler de façon créatrice le vide laisser par l'abolition du temps passé au travail. C'est une profonde mutation sociale et culturelle qui est en gestation et la «quête de sens» à laquelle ce recueil invite n'en deviendra que plus nécessaire.

Gilles DUSSAULT

Université Laval

Working-Class Experience: The Rise and Reconstitution of Canadian Labour, 1800-1980, by Bryon Palmer, Toronto, Butterworths, 1983, 320 pages, Index,

Working-Class Experience is a rare and valuable contribution to the study of Canadian labour history. Bryon Palmer is one of a small but growing number of social and labour historians who innovatively challenge orthodoxy in the interpretation of Canadian labour history. 
The book is ambitious, setting out to describe and comment on the development of Canadian labour from 1800 to 1980 . The attempt to go outside «labour organizations and labour politics" to examine "workers in their communities and families" makes the project, all the more, a major undertaking.

Working-Class Experience is best considered as a set of innovative historical conjectures that demand extensive research. As interesting as many of the hypotheses are, they need further substantiation.

The question that Palmer poses for himself is: "How has the working class experience been forged, how has the Canadian working class been made and remade over the course of two centuries?» (p. 5).

The argument that emerges from the book is that labour reached its cultural and political pinnicle in the 1880's. An era, according to Palmer, when the knights of labour «captured the support of the American working men and women» (p. 100) and "effectively bridged the gaps separating and fragmenting different labour factions) (p. 297). However, from the turn of the century, there was a fragmentation based on regionalism, religion, gender, ethnicity and skill differences. "The Canadian working class entered the 1920 's defeated and fragmented.» (pp. 183-84). From this point on working class culture became commercialized and individualist. Labour fought separate battles and feuded internally rather than uniting in their common interests.

Despite the many positive aspects of the book there are several drawbacks. The first that strikes one is the lack of precision in the major concepts the author uses. Repeatedly Palmer speakes of culture, working class culture, working class experience, and working class life experience, yet he never defines these concepts.

At times he refers to particular types of culture such as movement culture, mass culture, residual culture and emergent culture with no explanation (p. 106). One would have expected some links to be drawn between culture and consciousness for example but to no avail.

Another weakness lies in the conjectures he makes concerning the high tide of the working class in the 1880's. If we look at two of his hypotheses the problem becomes clear. He states that during the Eighties the Knights of Labour were the source of a process whereby the «question of class and sex could be considered as one» (p. 118). This was, according to Palmer, facilitated by taking up the organizing of women. At another point Palmer speaks of how the Knights facilitated «the bringing together of skilled and unskilled". Unfortunately, he never gives us any idea of the proportion of women or unskilled organized into the assemblies.

He notes that 10 percent of the local assemblies contained women but the real scope of involvement is unclear. This raises very real problems because in the absence of verification it would seem that he is simply making exaggerated claims. It is true that the Knights of Labour did, from 1881 on, allow women into the local assemblies. It is also true that, unlike the AFL or its Canadian supporters, the Knights organized both unskilled and skilled workers. This should not be underestimated but the extent to which they were successful should not be exaggerated either. Palmer seems to confuse the willingness to organize women and the unskilled with the success in doing so.

The book ends with a call for a retrun to the past through realizing the lessons of that past and applying them today. This appears to be a reflection of an unduly romantic vision of the late nineteenth century.

Working-Class Experience stands as a contribution to Canadian labour history which deserves careful consideration.

Jerry P. WHITE

McMaster University 